\title{
A STUDY ON AGRICULTURAL TRACTORS STEERING MECHANISM \\ 4-The steering Forces and power on the front wheels
} *Sarhan, A. M. M.

**Al - Katary, H. S. ***El- Awady, M. N.

\section{ABSTRACT}

The main aim of this research was to increase the operation efficiency of agricultural tractor to suit the conditions and potentials of the Egyptian farmer. This leads to increase the rates of the feddan production and raise the value of the yield per feddan. This meets the requirement to achieve the strategic goals of the agricultural development by modifying and developing the modern technology, especially the agricultural tractors to suit the local environment in all agricultural operations, including plowing. Laboratory experiments and statistical analysis for the data of the research were run and hydraulically steering was designed by suing a closed hydraulic circuit for the tractor. The main results obtained from the experiments are summarized in the following main points:

1-Mathematicl equations are derived to find the steering forces. 2Minimum values of the steering force and power $(5.211 \mathrm{kN}, 0.881 \mathrm{kw}) .3$ Saving power of the tractor to the maximum extent due to losses in steering. 4-Decreasing the costs maintaining the tractor by decreasing the costs maintaining of tractor steering equipments. 5-Decreasing the repeated technical problems in the steering equipments of the tractors. 6 The modification suits all the agricultural operations even for small holdings in Egypt.

\section{INTRODUCTION}

The agricultural tractor is the backbone of the Egyptian agriculture
because it does all the different field processes. It must be
improved to suit the conditions and potentials of the Egyptian farmer to increase the efficiency of its operation. This study aims to develop steering in particular. It aims to design a mechanism which can be controlled hydraulically to work on the front land-wheels.

*Ph. D. Stud. Dept. Eng., Fac. Agric., Al-Azhar Uninv. Cairo Egypt .

**Prof., Agric. Eng. Dept., Fac. Agric., Al-Azhar Uninv. Cairo Egypt .

***Emt. Prof., Agric. Eng. Dept., Fac. Agric., Ain Shams Uninv. 


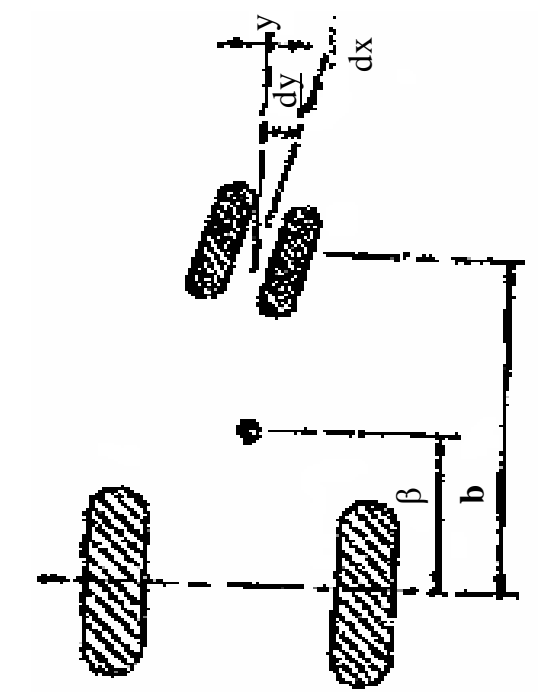

Fig (1): Geometry or tracior wneess wnen turning, Liljedahl and Strait (1962b).

Liljedahl et al. (1959) found that maximum forces were greater than the preload setting on both the "Case and John Deere" tractors. This improbably because the drivers were, for a short time, steering at a rate greater than be the power steering could follow and when the John Deere 70 was equipped with a front-end loader and driven in a figure of eight, power steering reduced the average steering force by $\mathbf{7 5}$ percent and the maximum by $\mathbf{6 7}$ percent . Under exactly the same conditions, use of the differential brakes had almost the same effect in reducing steering forces as power steering.

Liljedahl and Strait (1962a) assumed the steering forces are approximately the same as if the tractor were in motion on a rigid level plane surface.

Liljedahl and Strait $(\mathbf{1 9 6 2 b})$ assumed the radial force on the tractor wheels when turning is:

$$
F=\frac{W}{g} \times a=\frac{W}{g} \times \frac{V^{2}}{b} \times \frac{d y}{d x}
$$

Where: W: Weight of tractor, a: Acceleration, g: Gravity, b: Wheelbase of tractor, $\frac{\beta}{b}=\frac{1}{2}, \boldsymbol{\beta}$ : Distance from center of gravity to back wheels of tractor, V: Speed of tractor, $\mathbf{y}$ : Position of tractor between the rows, $\mathbf{x}$ : Position of tractor along the rows, as shown in Fig. (1). 
Richardson and Cooper (1970) found that the use of articulated steering resulted in decreased reactive performance when compared with performance in a straight line. Measures of reactive performance used in reaching this conclusion were drawbar pull and work index. Pull vs. slip and pull vs. soil strength comparisons were also made.

Katary (1976) reported that optimum tractor weight to drawbar pull ratio, at maximum reactive power efficiency, is 2.47 and 2.669 on asphalt and stubble field, respectively.

Kuipers (1991) found that the open furrow improves fraction acts as a steering aid for the tractor and reduces soil resistances. Nevertheless, systems that avoid subsoil compaction by not driving through the open furrow should be developed further.

Younis et al. (1991) reported the increase in the unit draft for chisel plow about $26 \%$ when the plowing depth increased from 10 to $20 \mathrm{~cm}$.

Sylvio (1993) developed a drawbar force transducer dimensioned for tractor power less than $\mathbf{1 0 0} \mathbf{~ k w}$ this double extended octagonal ring (DEOR) dynamometer was designed to simultaneously measure drawbar draft, vertical and side loads without altering the tractor-implement hitch point configuration. Side loads are derived from the differential draft outputs of the two extended octagonal ring (EOR).

Metwalli et al. (2002) showed that when soil conditions were in a good working range for tillage operations, a significant increase in impalement draft was observed with an increase in forward speed, plowing tillage depth and inflation pressure.

Metwalli et al. (2004) showed that the power requirement increased by increasing sub-soiling depth by $\mathbf{2 8 . 0 5 \%}$ and $\mathbf{7 2 . 9 3 \%}$ at 55 and $\mathbf{6 5} \mathrm{cm}$ respectively, compared with power at $\mathbf{4 5} \mathrm{cm}$ depth. The distance between shares had no effect on power requirement at the same depth (in their experiment).

\section{2-8: The moment:}

Liljedahl et al. (1959) indicated that when $(33.9 \mathrm{~m}$. N) torque was applied manually to the steering wheel, approximately $\mathbf{2 5}$ percent was absorbed by the steering soil.

Liljedahl and Strait (1962a) assumed that the moment on the vertical front-wheel spindle, or

kingpins, is:

$$
M=K \times \frac{d y}{d t}
$$


Where: K: is the tractor steering-force parameter which depends upon the speed and configuration of the tractor, $\mathbf{t}$ : time, $\mathbf{y}$ :position of tractor between the rows (function of time).

Liljedahl and Strait (1962b) assumed the moment on the front wheel spindle due to turning forces is:

$$
M_{a}=\frac{W C \beta}{g b^{2}} V^{2} \frac{d y}{d x}
$$

And for a four-wheel configuration:

$$
M=\left[\frac{W C \beta V}{g b^{2}}+\frac{W e \beta \sin \theta}{2 V b}\right] \frac{d y}{d t}=K \frac{d y}{d t}
$$

Where: C: Caster of front wheel, constant equal $2.54 \mathrm{~cm} . \theta$ : kingpin inclination, e: kingpin offset.

Bahnassi (1999) reported that mobility number as determined from an existing model can be used to specify the contact area, wheel developed torque and net thrust.

\section{2-9: The power:}

Liljedahl et al. (1959) stated that power steering reduced average, maximum forces by $\mathbf{5 0}$ percent on the "Case" tractor while cultivating corn and steering at a rate greater than the power steering could follow.

Katary (1976) reported the following main points:

1-Rolling resistance horsepower is higher on stubble field than on asphalt and increases by the increase in tractor speed. 2-Tractive power efficiency is lower at higher gear ratios. 3-Unit draft increases by the increase in tractor speed. 4-The slippage horsepower increases by the increase of drawbar pull at the same gear.

Awady (1979) found from his study to select the tractor power to suit the land holdings under the conditions of Kingdom of Saudi and Arab Republic of Egypt that the optimum tractor and implement size ranges between 14 and 17 HP.

Awady et al. (1981) carried out a study on a prototype designed and built by Egyptian "Small-scale agricultural activities project" to replace work stock animals. Their study included measurements of weight and its distribution, tillage capability, rolling resistance, and traction. They found that the total weight is $2600 \mathrm{n}$ distributed such that $1950 \mathrm{~N}$ falls on the rear 
traction-tyre and $650 \mathrm{~N}$ on the front supporting types. The weight /power ratio is thus $371 \mathrm{~N} / \mathrm{HP}$ or $520 \mathrm{~N} / \mathrm{kw}$-This ratio is so low that ballast weight of some $3000 \mathrm{~N}$ can be added to the unit. They pointed out also that rolling resistance ranges from 0.31 for motion on paved road at low speed to 0.86 on tilled soil at a higher speed. Although the figures are higher than for a single tyre, they are reasonable for the presence of motion transmission system and roughness of the land surface.

Kamel (1987) reported that the highest power unit (36kw) consumed less fuel per unit rate of work than other power units (23and 28kw)

\section{MATERIAL AND METHODS}

\section{A- Tractor:}

The Belarus tractor, 65B.HP (48.2kw) was common and widespread under Egyptian conditions. The tractor is multi purpose of the model 10M3-6KM. It was used in this research. The tractor was tested in plowing operation. After modification it was tested at agricultural tractors and machinery research laboratory, Agricultural Engineering Department, Faculty of Agriculture, Al-Azhar University.

\section{A-1: The tractor before modification:}

1- Gasoline engine $(65 \mathrm{HP}, 48.2 \mathrm{kw})$ at $1750 \mathrm{rpm}$. 2- Wheels (four wheels). 3-Minimum turning radius $=\mathbf{5} \mathrm{m}$.

\section{4- Steering system:}

(A): The components: It consists of: (1):Front axle; (2):Steering wheel to track width adjustment mechanism, determining the front wheel toe-in and checking toe-in of steering wheels; (3):Sector, spool, bushing, steering gear case, rack and oil drain pipeline (Fig.2); (4): Steering column, shock absorbers, sleeve, steering wheel shaft and steering wheel; (5): Steering gear, steering arm, steering shaft and warm gear; (6):Hydraulic steering servo, housing, spring washer and front cover; (7): Mounted at the middle position on the tractor.

(B): The disadvantages of power steering: 1- Difficult to repair and maintain. 2-Costs of repair and maintance. 3-The spare parts price is expensive. 4-Complex construction. 5-Mechanical steering system with addition to hydraulic steering servo. 


\section{A-2: The tractor after modification:}

The tractor was modified to overcome the problems encountered during the experimentation. The specifications of the tractor after modification are the same of tractor before modification but the different are follows:

\section{Apparatus of power hydraulic steering system:}

It was power hydraulic steering circuit, Fig (3):

The components: It consists of: 1- Reservoir (Transmission housing); 2Filter on intake; 2B-Filter on delivery; 3- Hydraulic pump. It consists of: A-Suction port; R-Lube fillets;

I): Bearings; 2):Seals; 3):Cover; 4):Key; 8):Bearing; 9):Bushes; 10):Pipe union; 11):Pump body; 12):Engine block; 13):Conductor pinion; 4-Rotary valve; 5, 9- Check valve; 6-Pressure relief valve; 7-Hydraulic steering control valve: It consists of: 1): Fixing screw; 2): Lower cap; 4):Spacer; 6):Stator; 7): Rotor; 8):Intermediate flange; 9):Non return valve; 10): Pressure limit valve; 14): Distributor; 15, 18):Anti-cavitations valve; 6):Distributor body; 17):Anti-shock valve; 19):Short circuit valve; 21):Grooved hub; 25):Upper cap. 8- Transfer pump/motor; 17-Sleeve; 18-Anti-shock valves (cylinder safety valves); 19-Anti-cavitations valves (Makeup valves); 22- Power cylinder: It consists of: 1):Cylinder; 2):Locking; 3): Bearing; 4):Gland; 5):“O” Ring; 6, 12, 13):Seal; 7): Wiper seal; 8):Gland locking; 9):Cylinder rod; 10):Retaining Ring; 11):Piston.

23- Ducts: A-Intake; B- Delivery; C-Return; D-Users on LH side of power cylinder; E-Users on RH side of power cylinder; F-Anti-shock valve discharge; G- Transmission oil cooler;

R-Flow regulator; W-Steering wheel.

\section{B-: Devices:}

\section{B-1: Surveying instruments:}

Tape steel $20 \mathrm{~m}$, steel ruler $30 \mathrm{~cm}$ and arrows were used for measuring and determining longitudinal dimensions. Pins were used for hitching the hydraulic dynamometer from both sides. Steel bolts and plastic threads were used for determining angle.

\section{B-2: The models:}

Models were made at the central workshops in the Ministry of Agriculture and Land Reclamation, to measure the steering angles. Models for the mechanizms were made of wooden bars, for the various geometrical 
dimensions. They generally conform to as small scale of $1: 2$. The model configurations had the variable dimensions shown in Table (1).

Table (1): The variable dimensions of the models.

\begin{tabular}{|c|c|c|c|c|c|c|}
\hline \multirow{2}{*}{ Configuration No. } & \multicolumn{6}{|c|}{ Dimensions in $\mathbf{m m}$. } \\
\hline & $\mathbf{W}$ & \multicolumn{2}{|c|}{$W / 2$ or $W / 3$} & TR & $\mathbf{r}$ & $\operatorname{Cot} \phi-\operatorname{Cot} \theta$ \\
\hline 1 & 960 & \multirow{4}{*}{$\frac{1}{3}$} & 480 & 912 & 192 & 0.39 \\
\hline 2 & 1110 & & 555 & 1050 & 222 & 0.45 \\
\hline 3 & 1260 & & 630 & 1200 & 252 & 0.51 \\
\hline 4 & 1410 & & 705 & 1340 & 282 & 0.58 \\
\hline 5 & 1110 & & $/ 3=370$ & 1050 & 222 & 0.45 \\
\hline
\end{tabular}

Their dimensions consist of fixed dimensions $(\operatorname{Cot} \theta=W / W B, W B=2450$, $\mathrm{e}=70 \mathrm{~mm}, \mathrm{r} / \mathrm{W}=\mathbf{0 . 2}$,

$\mathbf{T R} / \mathbf{W}=\mathbf{0 . 9 5}$ and $\gamma \mathbf{0}^{=\pi / 2}=\mathbf{9 0} 0^{\circ}$. The rest of dimensions are shown in (Fig.6).

A natural-size model was made of steel to Conform with the tractor modifications.

Where: $W B=$ Wheel base, $W=$ Steering pivots distance $(1110 \mathrm{~mm})$, $\mathbf{r}=$ Steering arm length, $\mathbf{T R}=$ Tie-rod length, $\phi=$ Outer front wheel steering angle, $\boldsymbol{\theta}=$ Inner front wheel steering angle, $\mathbf{e}=$ the distance between tie-rod and hydraulic cylinder base $\gamma_{0}=$ Upright angle, equal $(\boldsymbol{\pi} / \mathbf{2})$.

\section{B-3- Hydraulic dynamometer:}

A self recording hydraulic dynamometer model (VCD NESS UND REGELTECHNIK GMBH) used for measuring the forces situated on the front wheels. Its capacity is $\mathbf{5 0} \mathbf{~ k N}$ and its accuracy is $\mathbf{0 . 5} \mathbf{~ k N}$, by oilpressure gauge which measures oil pressure. Accuracy of the gauge is $\mathbf{0 . 1}$ bar or $10 \mathrm{kPa}$.

C- Experimental procedures: Forces, moments and power on the front wheel or its equivalents are required to steer the tractor over a given surface. The aim of this test was to determine the consumed power in steering of the tractor under test at average speed, different hydraulic cylinder; its rod-lengths were $(70.4,68.1,65.8,63.5,61.2$ and $58.9 \mathrm{~cm})$. 


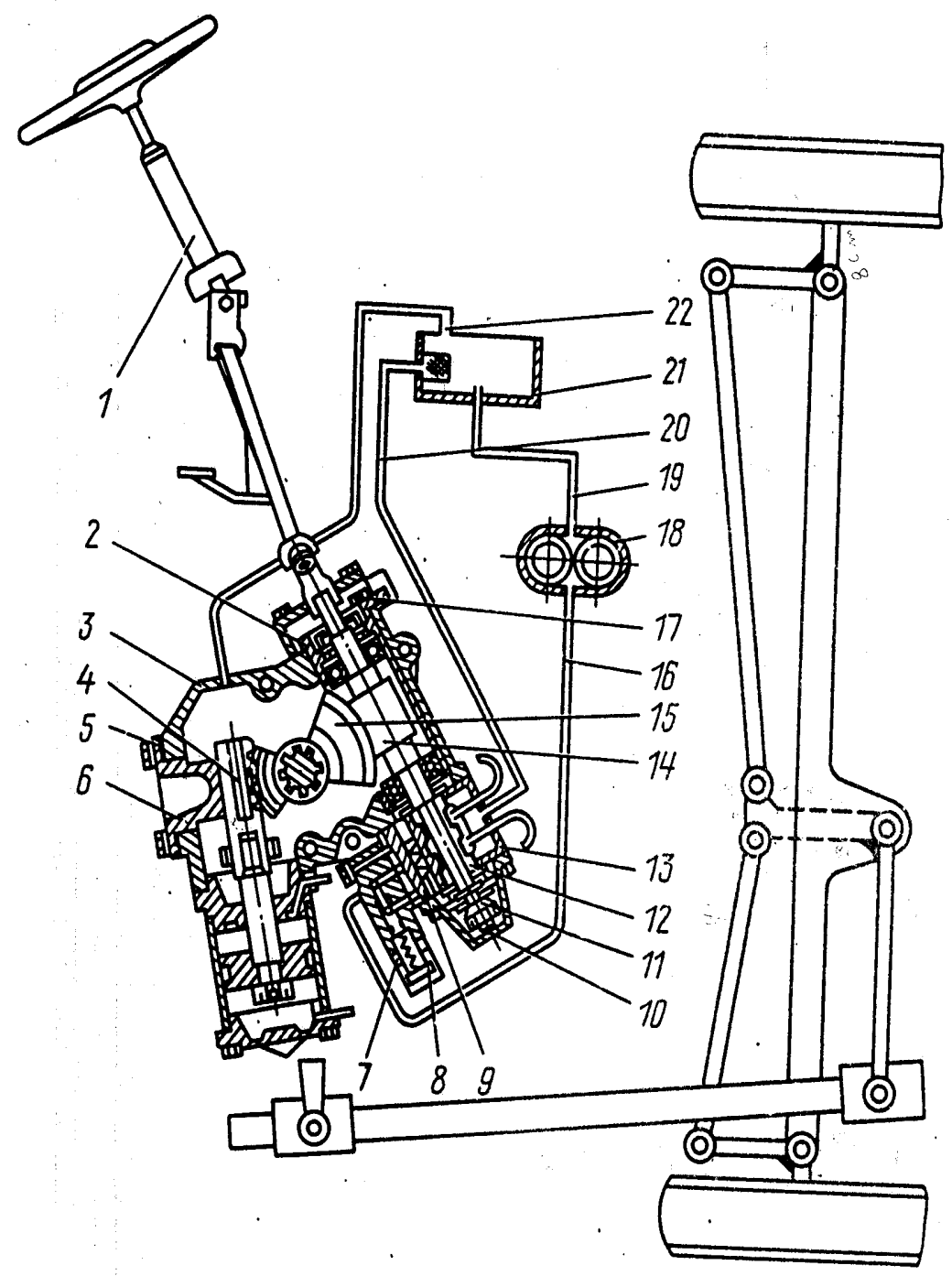

Fig. (2): Diagram of steering gear hydraulic Booster:

1- steering column ; 2- bushing ; 3- steering gear case ; 4- rack ; 5gasket ; 6- rest 7- lock nut ; 8- screw ; 9- safety valve ; 10- cover ; 11spherical nut ; 12 - spool ; 13- control valve housing ; 14- worm ;15sector ;16- oil delivery pipeline ; 17- bolt ; 18- oil pum ;19-oil suction pipeline ; 20- oil return pipeline ; 21 - oil tank ; 22- oil drain pipeline (Gurevich and Sorokin,1976). 


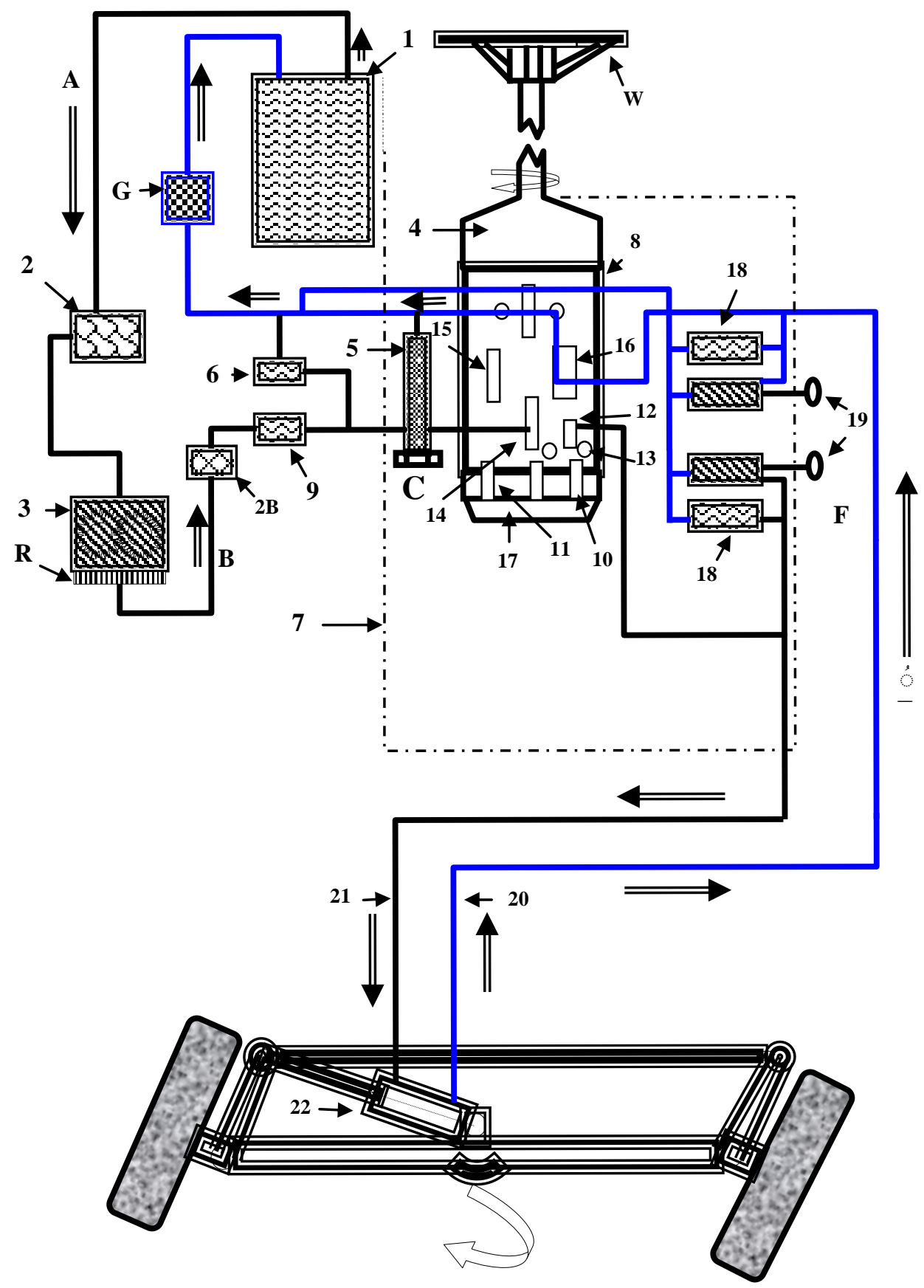

Fig. (3): Schematic drawing for apparatus of power hydraulic steering system. 
Four of the loads on front wheels were used (5.0, 5.5, 6.0, and $6.5 \mathrm{kN})$, speeds were (1st, $2 \mathrm{nd}, 3 \underline{\mathrm{rd}}$ and $4 \underline{\mathrm{th}}$ gears), four replicates and four of values of W/WB were used $(0.39,0.45,0.51,0.58)$. Five traction surfaces were used (namely, air, concrete surface, clay, sandy clay and sandy surfaces). The tractor having power of 65 B.HP (48.2 kw) was used to draw the tested tractor and the forces and moments were determined through recording hydraulic dynamometer. The measured distance of the test course was fixed throughout the test at 100 meters for each run, and the average speed was calculated relative to the travel time in sixteen replicates, the forces, moments and power at the average speed, different traction surfaces and soil conditions.

D-Using mathematical analysis for the common-center-steering systems of tractors:

Analytical program was derived for 4-bar mechanism (steering mechanism) referring to Figs (4 through 6), based on the mechanism data: WB: wheelbase $(2450 \mathrm{~mm}), \mathrm{W}$ : Steering pivots distance $(1110 \mathrm{~mm})$, r: Steering arm length $(222 \mathrm{~mm}), \theta_{0}$ :Initial steering arm angle $\left(8.29^{\circ}\right)$, TR: Tie-rod length $(105 \mathrm{~cm}), \theta$ : Inner front wheel steering angle, $\phi$ :Outer front wheel steering angle; I: Instantaneous center. Equations of the forces, moments and required steering power are given as shown in Figs (4 through 6) .

Tractor engine power required for steering operation can be determined by using the following equation:

$$
\mathrm{P}_{\mathbf{t}}=Q \times \mathrm{p}
$$

The above equation gives: $\quad P_{t}=\frac{F \times v}{100 \times 75}$

Which can be rearranged to find $P_{a c t}$ a given $P_{t}$ and $P_{a i r}$ as follows: $\mathrm{P}_{\text {act }}=\mathrm{P}_{\mathbf{t}}-\mathrm{P}_{\text {air }}$....Where: $\mathrm{P}_{\mathbf{t}}$ : is steering power in $\mathbf{k w} ; \mathbf{Q}=$ Oil pump rate of discharge in $\mathrm{m}^{\mathbf{3}} / \mathrm{s} ; \mathbf{Q}=\mathbf{A} \times \mathbf{V} ; \mathbf{A}=$ Piston area in $\mathrm{m} ; \mathbf{p}=$ Oil pressure in $\mathbf{k P a}$; $\mathbf{V}=$ the piston speed in $\mathrm{m} / \mathrm{s}$. In this case piston forward speed= $(0.17 \mathrm{~m} / \mathrm{s})$; and backward speed $=(0.20 \mathrm{~m} / \mathrm{s}) ; \mathrm{P}_{\text {act }}=$ Actual steering power in kw; $\mathrm{P}_{\mathrm{air}}=$ the total (theoretical) steering power for air treatment losses in inside friction in $\mathbf{k w}$. 


\section{RESULTS AND DISCUSSION}

The study was carried out to indicate effects of the cylinder length and the tractor dimensions at different geometric proportions on the following factors:

\section{(1): Steering force variation with angle:}

Figs (4 through 6), illustrate effect of the steering angle, the piston steering angles, constant dimensions of the values of $\left(\mathbf{F}_{\mathbf{1}}\right)$ and $\left(\mathbf{F}_{\mathbf{2}}\right.$ or $\left.\mathbf{F}_{\mathbf{t}}\right)$ at different geometric proportions. The steering forces $\left(\mathbf{F}_{\mathbf{1}}, \mathbf{F}_{2}\right)$ equations can be derived as follow:

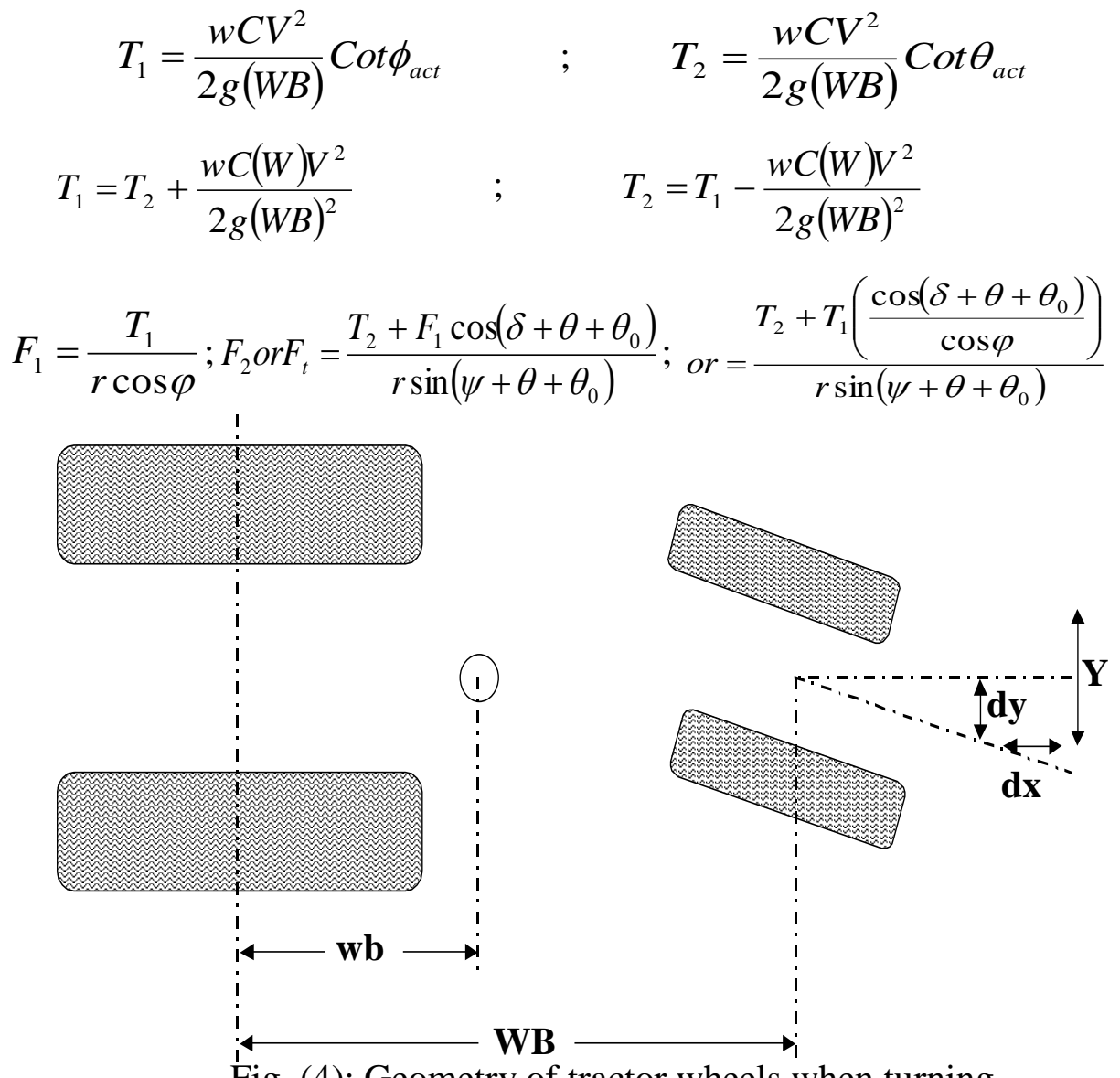

Fig. (4): Geometry of tractor wheels when turning. 


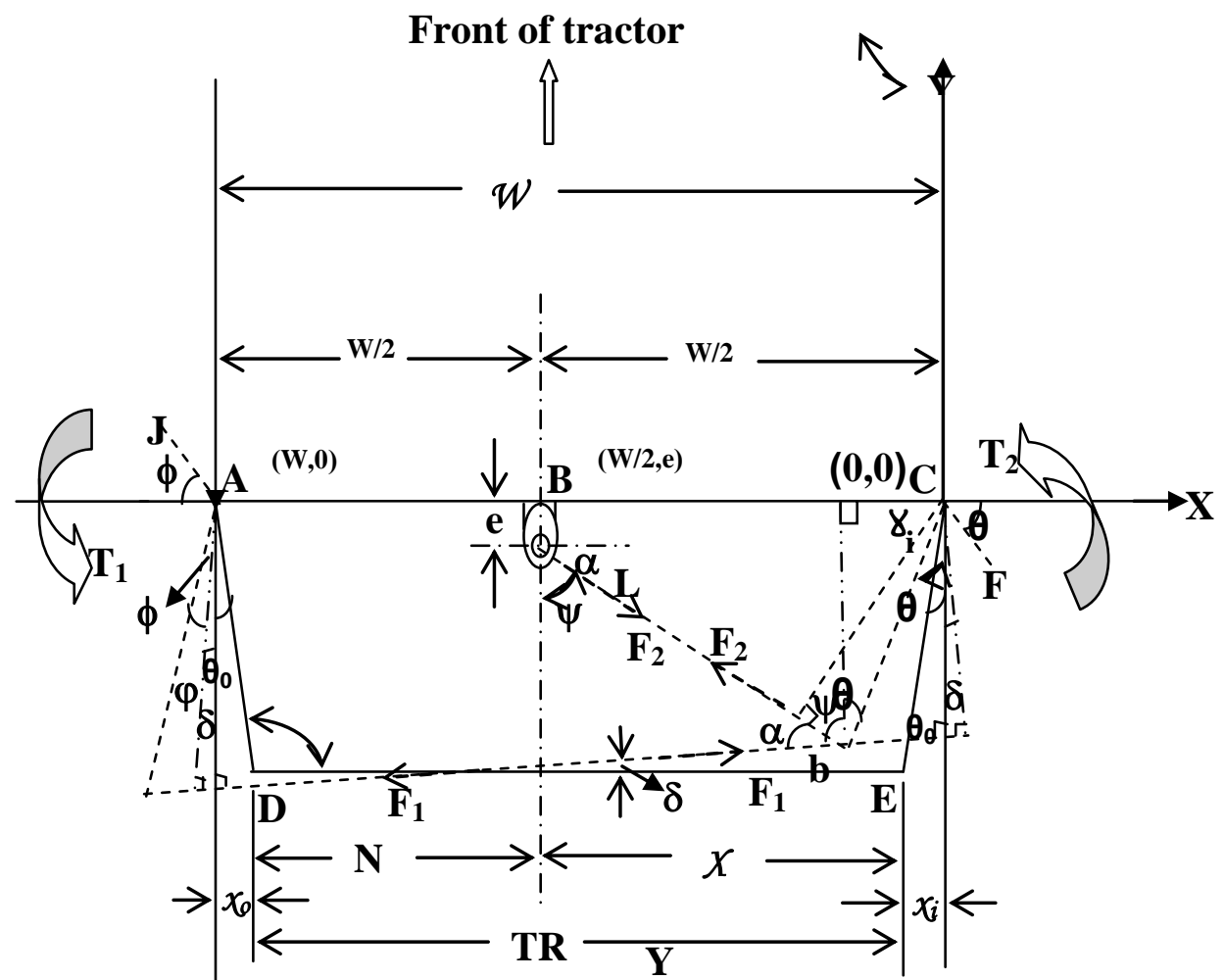

Fig. (5): Schemaßj diagram of the moment on the front - wheel spindle due to turning forces.

Where: $\mathrm{T}_{1}$ : The moment on piston surface due to oil pressure in kn.m; $\mathrm{T}_{2}$ : The moment on front wheel spindle due to turning forces in kn.m; $\psi$ : The piston angle with vertical axis or perfect angle for piston steering angle equal $(\pi / 2-\propto) ; \delta$ :The confined angle between the vertical line and the vertical axis or the confined angle between the old and new position for tie rod; $\varphi$ : The confined angle between the vertical line and new positions for the steering arm; $\theta_{\mathrm{o}}$ : Initial steering arm angle $\left(8.29^{\circ}\right)$; $\theta$ :Inner steering angle; r: Steering arm length, $\mathrm{cm}$.

From Fig. (7), it is clear that for all the traction surfaces, the theoretical steering forces $\left(F_{2}\right.$ or $\left.F_{t}\right)$ increased with the inner front wheels steering angle $(\theta)$. Values of $\left(F_{2}\right.$ or $\left.F_{t}\right)$ varied from about $(5.01$ to $15.94 \mathrm{kN})$ at values of $(\theta)$ varying from about 0,2 to 50 degrees, respectively for value of W/WB 0.45 . 


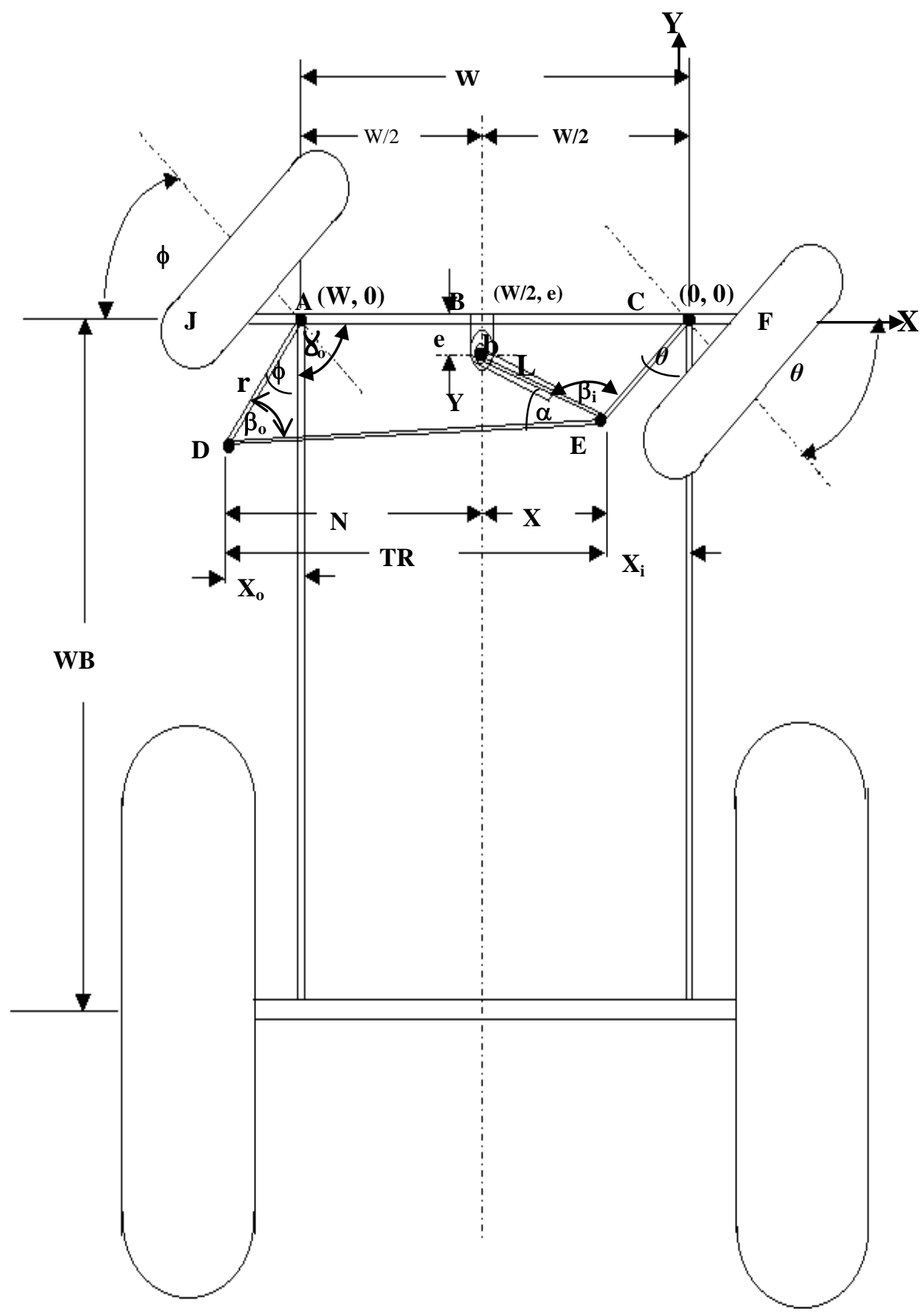

Fig. (6): Steering geometry during a turn of the tractor to the right direction and dimensions of the mechanizm ( $\theta$ : inner; $\phi$ : outer steering angles). 


\section{(2): Effect of the load and the cylinder length on the steering force and power:}

From Figs (8 and 10), it is clear that for all loads, the steering force and power increased with the traction surface loosening. Values of the theoretical steering force $\left(\mathrm{F}_{\mathrm{t}}\right)$ and power $\left(\mathrm{P}_{\mathrm{t}}\right)$ were $(0.860,6.592,7.027$, $7.393,7.482 \mathrm{kN}) ;(0.145,1.062,1.188,1.25,1.265 \mathrm{kw})$, also values the actual steering forces $\left(\mathrm{F}_{\mathrm{act}}\right)$ and power $\left(\mathrm{P}_{\mathrm{act}}\right)$ were $(5.732,6.167,6.533$, $6.622 \mathrm{kN}) ;(0.969,1.042,1.104,1.119 \mathrm{kw})$ at surfaces of about concrete, clay, sandy clay, and sandy, respectively.

Figs (9 and 11), indicate that for all the traction surfaces, the steering force, power increased with the hydraulic cylinder length probably due to the increase of the steering angle. Values of the theoretical steering force $\left(\mathrm{F}_{\mathrm{t}}\right)$, power $\left(\mathrm{P}_{\mathrm{t}}\right)$; the actual steering forces $\left(\mathrm{F}_{\mathrm{act}}\right)$ and power $\left(\mathrm{P}_{\text {act }}\right)$ varied from about (4.939 to $9.051 \mathrm{kN}) ;(0.835$ to $1.530 \mathrm{~kW}) ;(4.216$ to 7.725 $\mathrm{kN}) ;(0.713$ to $1.306 \mathrm{kw})$ at the hydraulic cylinder length varying from about (58.9 to $70.4 \mathrm{~cm})$, respectively.

Figs (8 through 11), show that for all the traction surfaces and the cylinder length the steering force and power increased with the load on front wheels probably due to the increase of the contact area. Values of the theoretical steering force $(\mathrm{Ft})$, power $(\mathrm{Pt})$; the actual steering forces(Fact) and power(Pact) varied from about (5.127 to $6.616 \mathrm{kN}) ;(0.866$ to 1.119 $\mathrm{kw}) ;(4.267$ to $5.756 \mathrm{kN})$; (0.721 to $0.973 \mathrm{kw})$ at loads on front wheels varying from about (5.0 to $6.5 \mathrm{kN}$ ), respectively.

(3): Effect of the speed and the cylinder length on the steering force and power:

From Figs ( 8 and 10), it is clear that for all speeds, the steering force and power increased with the traction surfaces loosening. Values of the theoretical steering force $\left(\mathrm{F}_{\mathrm{t}}\right)$ and power $\left(\mathrm{Pt}_{\mathrm{t}}\right)$ were $(0.86,6.156,6.563$, $6.902,6.988 \mathrm{kN}) ;(0.145,1.041,1.109,1.166,1.181 \mathrm{kw})$, also values the actual steering forces (Fact) and power (Pact) were (5.296, 5.703, 6.042, $6.128 \mathrm{kN}) ;(0.9,0.963,1.021,1.036 \mathrm{kw})$ at the traction surfaces of about concrete, clay, sandy clay and sandy, respectively.

Figs (9 and 11), indicate that for all the traction surfaces, the steering force and power increased with the hydraulic cylinder length probably due to the increase of the steering angle. Values of the theoretical steering 
force $\left(\mathrm{F}_{\mathrm{t}}\right)$, power $\left(\mathrm{P}_{\mathrm{t}}\right)$; the actual steering force $\left(\mathrm{F}_{\mathrm{act}}\right)$ and power $\left(\mathrm{P}_{\mathrm{act}}\right)$ varied from about (4.623 to $8.47 \mathrm{kN}) ;(0.781$ to $1.432 \mathrm{kw}) ;(3.9$ to 7.144 $\mathrm{kN}) ;(0.658$ to $1.207 \mathrm{kw})$ at the hydraulic cylinder length varying from about (58.9 to $70.4 \mathrm{~cm})$, respectively.

Figs (8 through 11), show that for all the traction surfaces and all the hydraulic cylinder length the steering force, power decreased with increasing speed of the tractor. Values of the theoretical steering force $\left(\mathrm{F}_{\mathrm{t}}\right)$, power $\left(\mathrm{P}_{\mathrm{t}}\right)$; the actual steering forces $\left(\mathrm{F}_{\mathrm{act}}\right)$ and power $\left(\mathrm{P}_{\mathrm{act}}\right)$ varied from about (4.518 to $6.609 \mathrm{kN}) ;(0.764$ to $1.117 \mathrm{kw}) ;(3.658$ to $5.749 \mathrm{kN}) ;($ 0.618 to $0.972 \mathrm{kw}$ ) at speeds of the tractor varying from about (1 $\underline{\mathrm{st}}$ to $4 \underline{\text { th }}$ gears), respectively.

\section{(4): Effect of the W/WB and the cylinder length on the steering force and power:}

From Figs (8 and 10), it is clear that for all the value of $\mathrm{W} / \mathrm{WB}$, the steering force and power increased with increasing the traction surface loosening. Values of $(\mathrm{Ft})$ and $(\mathrm{Pt})$ were $(0.86,6.171,6.578,6.917,7.104$ $\mathrm{kN}) ;(0.145,1.045,1.112,1.17,1.201 \mathrm{kw})$, also values the actual steering forces(Fact) and power(Pact) were (5.311, 5.718, 6.057, 6.244 $\mathrm{kN}) ;(0.899,0.966,1.025,1.056 \mathrm{kw})$ at the traction surfaces of about concrete, clay, sandy clay, and sandy, respectively.

Figs (9 and 11), indicate that for all the traction surfaces, the steering force and power increased with the hydraulic cylinder length probably due to the increase of the steering angle. Values of the theoretical steering force $\left(\mathrm{F}_{\mathrm{t}}\right)$, power $\left(\mathrm{P}_{\mathrm{t}}\right)$; the actual steering forces $\left(\mathrm{F}_{\mathrm{act}}\right)$ and power $\left(\mathrm{P}_{\mathrm{act}}\right)$ varied from about (4.623 to $8.489 \mathrm{kN}) ;(0.783$ to $1.435 \mathrm{kw}) ;(3.9$ to 7.163 $\mathrm{kN})$; (0.661 to $1.21 \mathrm{kw})$ at the hydraulic cylinder length varying from about (58.9 to $70.4 \mathrm{~cm})$, respectively.

Figs (8 through 11), show that for all traction surfaces and all the hydraulic cylinder length the steering force and power increased with the value of $\mathrm{W} / \mathrm{WB}$ probably due to the increase of the steering angle. Values of the theoretical steering force $\left(\mathrm{F}_{\mathrm{t}}\right)$, power $\left(\mathrm{P}_{\mathrm{t}}\right)$; the actual steering forces $\left(\mathrm{F}_{\mathrm{act}}\right)$ and power $\left(\mathrm{P}_{\mathrm{act}}\right)$ varied from about $(4.676$ to $6.541 \mathrm{kN}) ;(0.790$ to $1.107 \mathrm{kw}) ;(3.816$ to $5.681 \mathrm{kN}) ;(0.645$ to $0.962 \mathrm{kw})$ at values of W/WB varying from about ( 0.39 to 0.58$)$, respectively. 


\section{SUMMARY AND CONCLUSION}

The present study was carried out by using two tractors mounted type chisel plough of 7 tines in two rows locally industrial were used, the Belarus tractor, 65B.HP (48.2 kw) was usage common and widespread under Egyptian conditions. The tractor before, after common and widespread under Egyptian conditions. The tractor before, after modification (this modification allowed tested tractor to decrease the turning radius from 5 to $\mathbf{1 . 5} \mathrm{m}$ and decrease the friction between the front wheels and the steering equipments) were constructed and tested at agricultural tractors and machinery research laboratory, Agricultural Engineering Department, Faculty of Agriculture, Al-Azhar University. The main results obtained from experiments are summarized under the following main points:

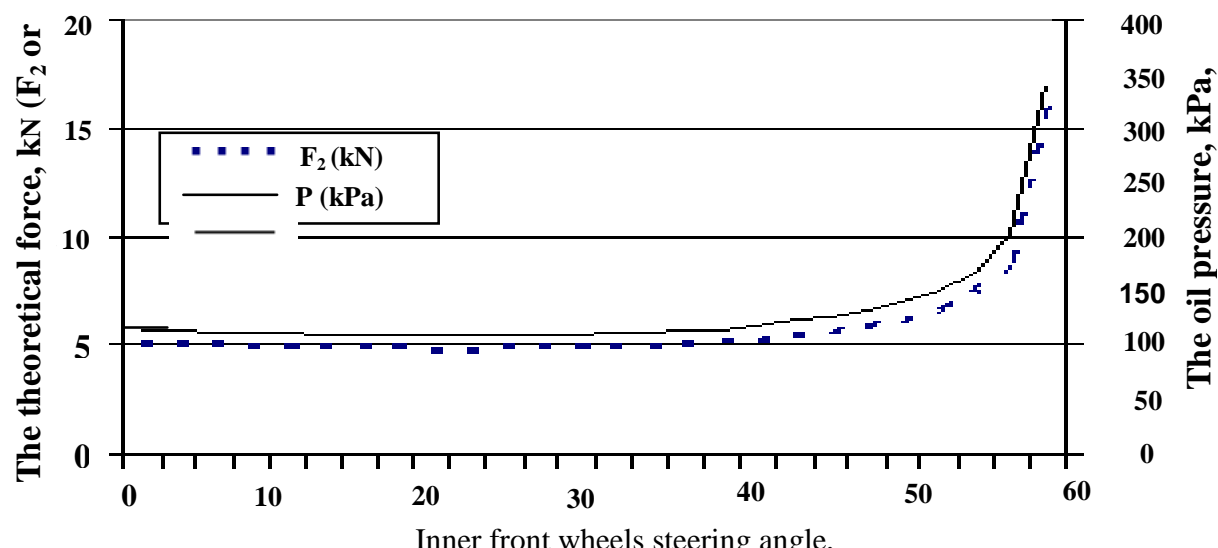

Fig.(7):Effect of the inner front wheel steering angle on the theoretical steering forces on piston surface $\left(\mathrm{F}_{2}\right.$ or $\left.\mathrm{F}_{\mathrm{t}}\right)$ and the oil pressure value on the piston surface for 4-bar steering mechanism at value of $\mathrm{W} / \mathrm{WB}=0.45$.

\section{(1): Steering force variation with angle:}

The theoretical steering forces $\left(\mathrm{F}_{2}\right.$ or $\left.\mathrm{F}_{\mathrm{t}}\right)$ increased with the inner front wheels steering angle $(\theta)$. Values of $\left(F_{2}\right.$ or $\left.F_{t}\right)$ varied from about (5.01 to $15.94 \mathrm{kN})$ at values of $(\theta)$ varying from about 0,2 to 50 degrees, respectively for value of W/WB 0.45 .

(2): Effect of the load and the cylinder length on the steering force and power:

The steering force and power increased with the traction surface loosening. Values the theoretical steering force $\left(\mathrm{F}_{\mathrm{t}}\right)$ and power $\left(\mathrm{P}_{\mathrm{t}}\right)$ were 

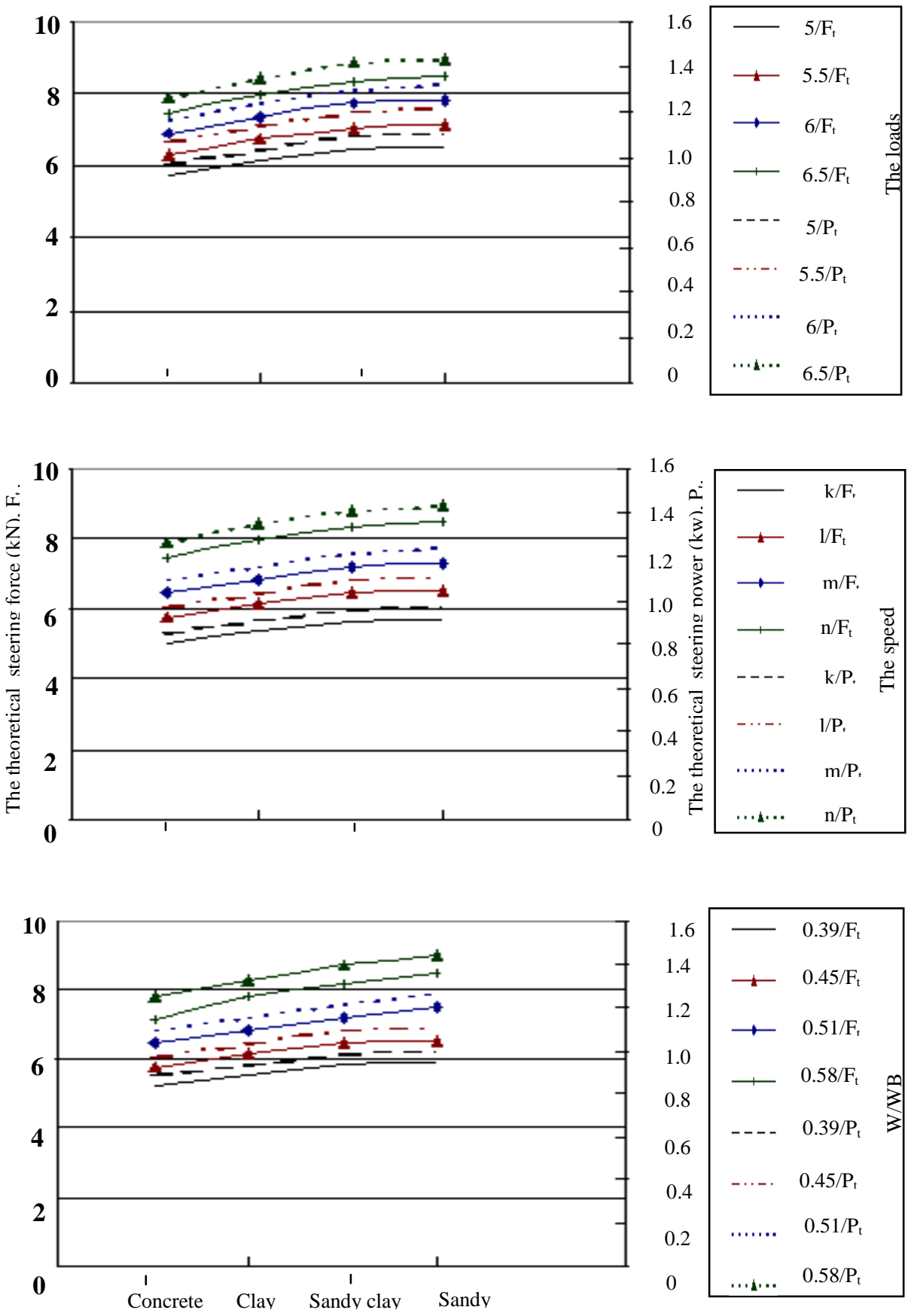

The traction surfaces.

Fig. (8): Effect of the traction surface, load, the speed, the value of (W/WB) on the theoretical steering force and power. 

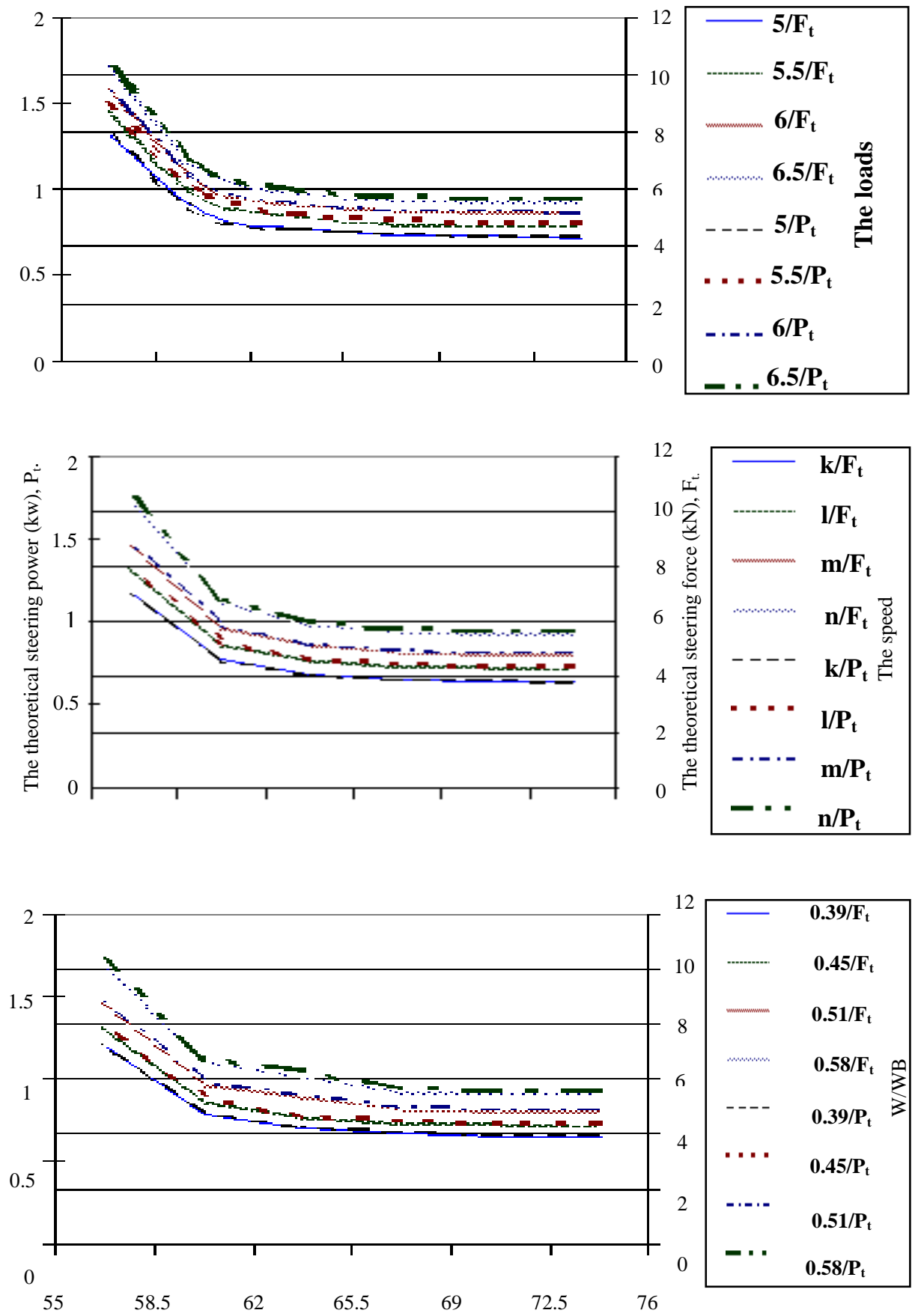

The hydraulic cylinder lengths (cm, L.).

Fig. (9): Effect of hydraulic cylinder length, load, the speed, the value of (W/WB) the theoretical steering force and power. 

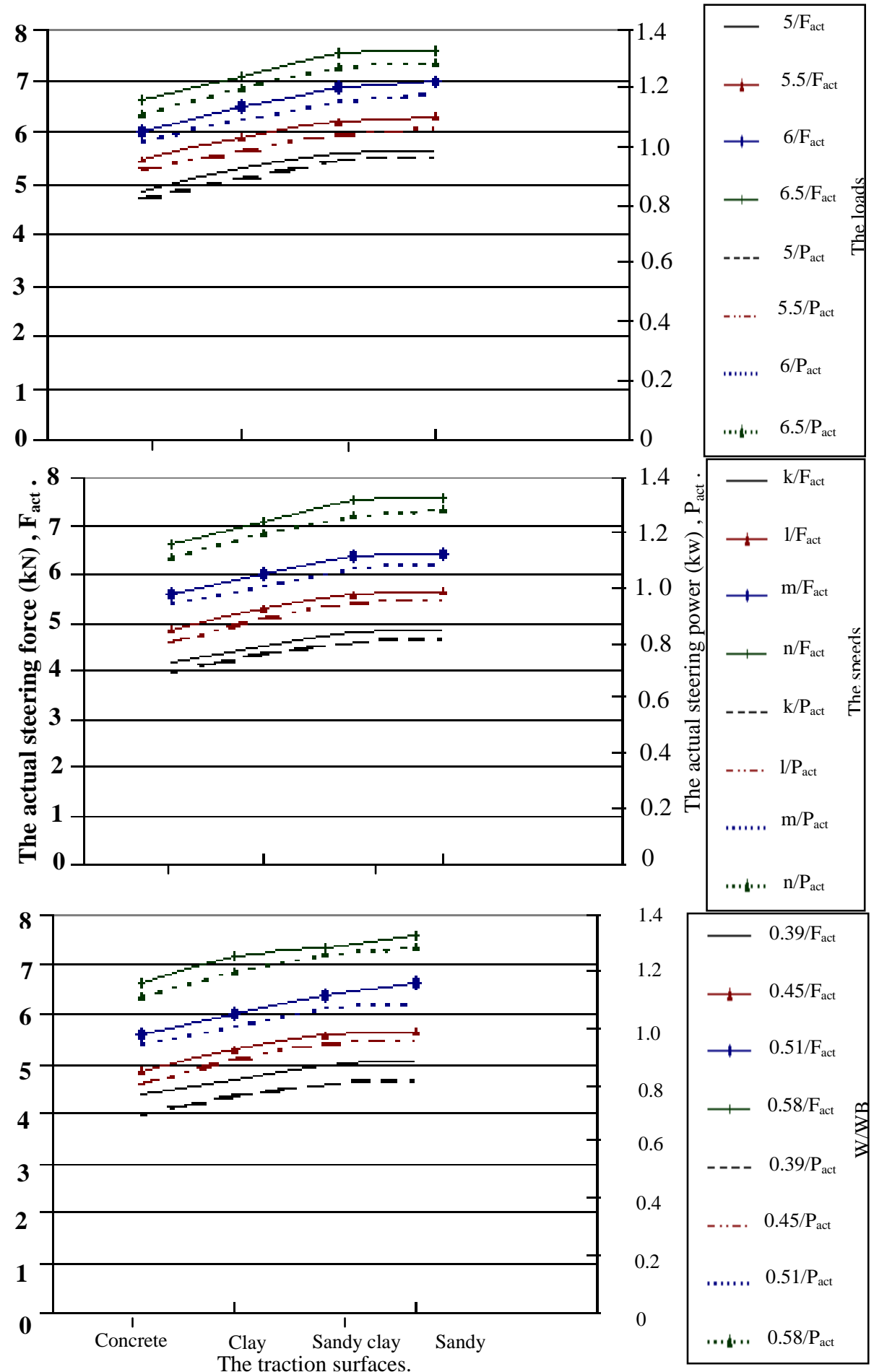

Fig. (10): Effect of the traction surface, load, the speed, the value of (W/WB) On the actual steering force and power. 

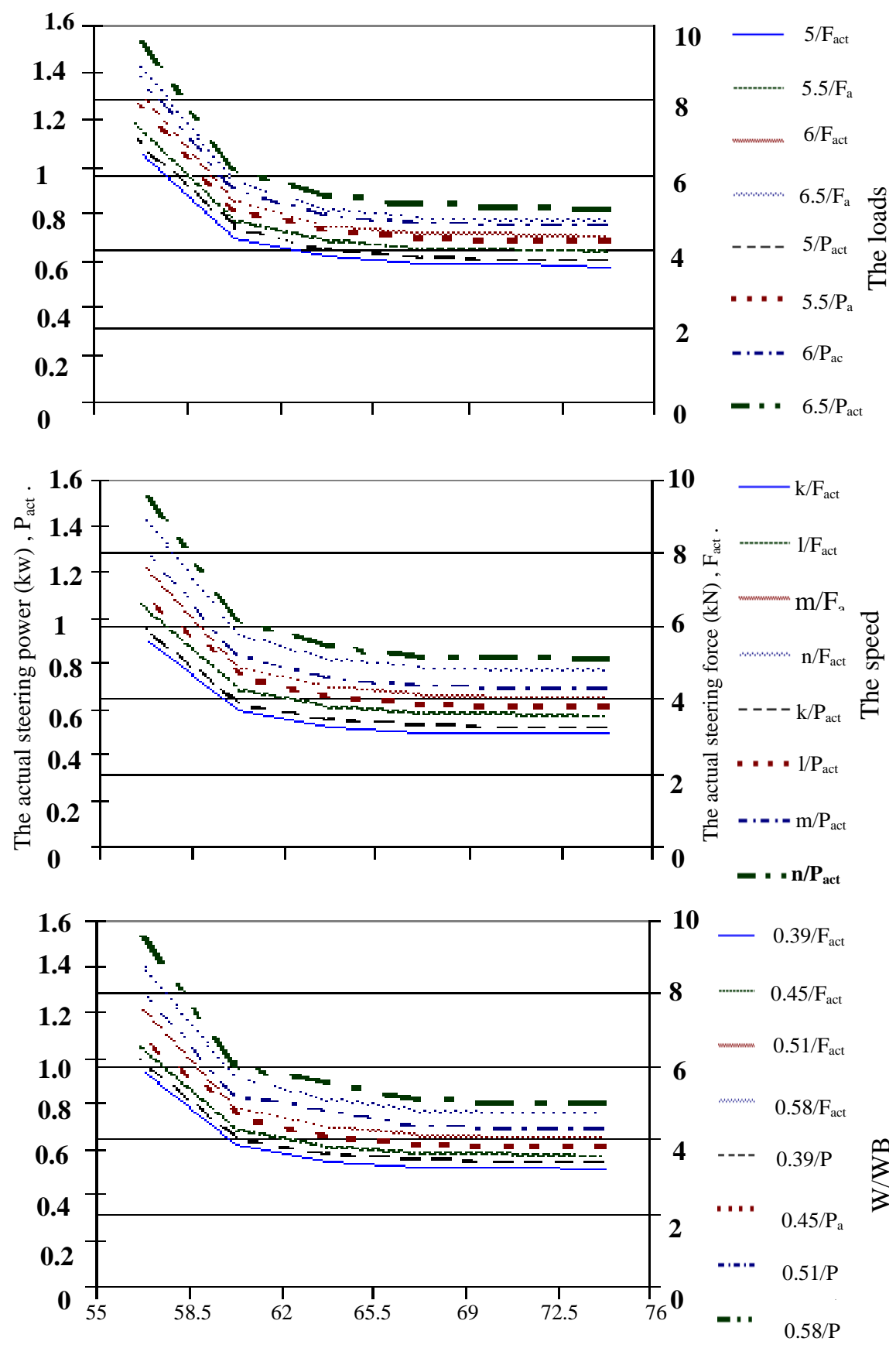

The hydraulic cylinder lengths (cm, L.).

Fig. (11): Effect of hydraulic cylinder length, load, the speed, the value of (W/WB) on the actual steering force and power. 
$(0.860,6.592,7.027,7.393,7.482 \mathrm{kN}) ;(0.145,1.062,1.188,1.25,1.265$ $\mathrm{kw})$, also values of the actual steering forces $\left(\mathrm{F}_{\mathrm{act}}\right)$ and power $\left(\mathrm{P}_{\mathrm{act}}\right)$ were $(5.732,6.167,6.533,6.622 \mathrm{kN}) ;(0.969,1.042,1.104,1.119 \mathrm{kw})$ at surfaces of about concrete, clay, sandy clay, and sandy, respectively.

The steering force, power increased with the hydraulic cylinder length. Values of the theoretical steering force $\left(\mathrm{F}_{\mathrm{t}}\right)$, power $\left(\mathrm{P}_{\mathrm{t}}\right)$; the actual steering forces $\left(\mathrm{F}_{\mathrm{act}}\right)$ and power $\left(\mathrm{P}_{\mathrm{act}}\right)$ varied from about (4.939 to $\left.9.051 \mathrm{kN}\right) ;(0.835$ to $1.530 \mathrm{kw}) ;(4.216$ to $7.725 \mathrm{kN}) ;(0.713$ to $1.306 \mathrm{kw})$ at the hydraulic cylinder length varying from about $(58.9$ to $70.4 \mathrm{~cm})$, respectively.

The steering force and power increased with the load on front wheels. Values of the theoretical steering force $(\mathrm{Ft})$, power $(\mathrm{Pt})$; the actual steering forces(Fact) and power(Pact) varied from about $(5.127$ to $6.616 \mathrm{kN})$; (0.866 to $1.119 \mathrm{kw}) ;(4.267$ to $5.756 \mathrm{kN}) ;(0.721$ to $0.973 \mathrm{kw})$ at loads on front wheels varying from about $(5.0$ to $6.5 \mathrm{kN})$, respectively.

\section{(3): Effect of the speed and the cylinder length on the steering force} and power:

The steering force and power increased with the traction surfaces loosening. Values of the theoretical steering force $(\mathrm{Ft})$ and power $(\mathrm{Pt})$ were $(0.86,6.156,6.563,6.902,6.988 \mathrm{kN}) ;(0.145,1.041,1.109,1.166$, $1.181 \mathrm{kw}$ ), also values of the actual steering forces (Fact) and power (Pact) were (5.296, 5.703, 6.042, 6.128 kN); (0.9, 0.963, 1.021, $1.036 \mathrm{kw})$ at the traction surfaces of about concrete, clay, sandy clay and sandy, respectively.

The steering force and power increased with the hydraulic cylinder length. Values of the theoretical steering force $\left(\mathrm{F}_{\mathrm{t}}\right)$, power $\left(\mathrm{P}_{\mathrm{t}}\right)$; the actual steering force $\left(\mathrm{F}_{\mathrm{act}}\right)$ and power $\left(\mathrm{P}_{\mathrm{act}}\right)$ varied from about $(4.623$ to $8.47 \mathrm{kN}) ;(0.781$ to $1.432 \mathrm{kw}) ;(3.9$ to $7.144 \mathrm{kN}) ;(0.658$ to $1.207 \mathrm{kw})$ at the hydraulic cylinder length varying from about (58.9 to $70.4 \mathrm{~cm}$ ), respectively.

The steering force, power decreased with increasing speed of the tractor. Values of the theoretical steering force $\left(\mathrm{F}_{\mathrm{t}}\right)$, power $\left(\mathrm{P}_{\mathrm{t}}\right)$; the actual steering forces $\left(\mathrm{F}_{\mathrm{act}}\right)$ and power $\left(\mathrm{P}_{\mathrm{act}}\right)$ varied from about $(4.518$ to $6.609 \mathrm{kN})$; ( 0.764 to $1.117 \mathrm{kw})$; (3.658 to $5.749 \mathrm{kN}) ;(0.618$ to $0.972 \mathrm{kw})$ at speeds of the tractor varying from about (1 $\underline{\mathrm{st}}$ to $4 \underline{\mathrm{th}}$ gears), respectively.

(4): Effect of the W/WB and the cylinder length on the steering force and power: 
The steering force and power increased with increasing the traction surface loosening. Values of $(\mathrm{Ft})$ and $(\mathrm{Pt})$ were $(0.86,6.171,6.578,6.917$, $7.104 \mathrm{kN}) ;(0.145,1.045,1.112,1.17,1.201 \mathrm{kw})$, also values of the actual steering forces $\left(\mathrm{F}_{\mathrm{act}}\right)$ and power (Pact) were $(5.311,5.718,6.057,6.244$ $\mathrm{kN}) ;(0.899,0.966,1.025,1.056 \mathrm{kw})$ at the traction surfaces of about concrete, clay, sandy clay, and sandy, respectively.

The steering force and power increased with the hydraulic cylinder length. Values of the theoretical steering force $\left(\mathrm{F}_{\mathrm{t}}\right)$, power $\left(\mathrm{P}_{\mathrm{t}}\right)$; the actual steering forces $\left(\mathrm{F}_{\mathrm{act}}\right)$ and power $\left(\mathrm{P}_{\mathrm{act}}\right)$ varied from about $(4.623$ to $8.489 \mathrm{kN})$; ( 0.783 to $1.435 \mathrm{kw})$; (3.9 to $7.163 \mathrm{kN}) ;(0.661$ to $1.21 \mathrm{~kW})$ at the hydraulic cylinder length varying from about (58.9 to $70.4 \mathrm{~cm})$, respectively.

The steering force and power increased with the value of W/WB. Values of the theoretical steering force $\left(\mathrm{F}_{\mathrm{t}}\right)$, power $\left(\mathrm{P}_{\mathrm{t}}\right)$; the actual steering forces $\left(\mathrm{F}_{\mathrm{act}}\right)$ and power $\left(\mathrm{P}_{\mathrm{act}}\right)$ varied from about $(4.676$ to $6.541 \mathrm{kN}) ;(0.790$ to $1.107 \mathrm{kw})$; (3.816 to $5.681 \mathrm{kN}) ;(0.645$ to $0.962 \mathrm{kw})$ at values of W/WB varying from about ( 0.39 to 0.58$)$, respectively, saving power of the tractor to the maximum extent due to losses in steering and increased the tractor efficiency.

\section{REFERENCES}

Awady, M.N. (1979). "Selection of the tractor power to suit of land holdings and affecting factors." Document No. 16 Academy of scientific. Research and Technology, Cairo.

Awady, M.N.; M.N. Mostafa; and S.Y. Ghoniem (1981). "Studies on an agricultural power unit small tractor." Res. Bull. 1579, Agric. in Shams Univ.

Bahnassi, A.M.F. (1999).“ Effect of tyre-soil interaction on tractor performance. " Ph. D. Th., Ag. Mech. Dept., Fac. of Ag. Mansoura U., : 133-135.

Gurevich, A.; and Sorokin, E. (1976). "Tractors." Mir. Pub., Moscow: 13-16.

Kamel, M.M. (1987). "Selecting the optimum sized tractor." M. Sc/Th., Fac. of Agric., Ain Shams Univ., Egypt: 86-89 . 
Katary, H.S. (1976). "A study on some specifications of tractor most suitable for Egyptian conditions." M.Sc. Th. Fac. of Agric., El-Azhar Univ., Cairo, Egypt: 118-123.

Kuipers, H. (1991). "Agronomic aspects of ploughig and nonploughing." Soil-and-Tillage-Res., 21:1-2, 167-167; 37 ref.

Liljedahl, J.B.; R. Gluck; and M.E. Schroeder (1959). "Steering-force requirements of wheel tractors.” Ag. Eng., Sept., : 522-525.

Liljedal, L.A. and Strait, J. (1962a)."Automatic tractor steering.” Ag. Eng., June: 332-335.

Liljedal, L.A. and Strait, J. (1962b). "Automatic tractor steering.” Ag. Eng., July: 407-409.

Metwalli S. M.; Mohammed H.A. Kabeel; Abdul wahed M. Abou Karima; and

Samy El-S.Bader. (2002). "Effect of forward speed, plowing depth and inflation pressure on tractor performance during tillage." Misr J. Ag. Eng., 19(3): 597-610.

Metwalli, S.M.; Sayed, M.A.; and Osman A.M. (2004). "Effect of subsoiling depth and share distance on soil physical properties, power and sunflower yield in calcareous soils.” Misr J. Ag. Eng., 21(2): 509-520.

Richardson, B.Y. and A.W. Cooper (1970). "Effects of articulated steering on tractive performance of a rubber-tired logging tractor." Trans. ASAE: 633-635.

Sylvio (1993). "Improved double error drawbar pull transducer from 3-D forces measurements.” ASAE paper No. 93-3076: 930-934.

Younis, S.M.; N.A. Shaibon; and A.M. Zein El-Din (1991). "Evaluation of eleven tillage treatments used for cultivation of bean, wheat and cotton crops in Egyptian salty soil." Misr. J. Ag. Eng., 8 (I):11-26. 


\section{الملخص العربي \\ دراسة على كفاءة أجهزة توجيه الجرارات الزراعية المجية

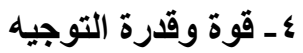

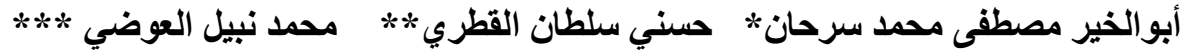

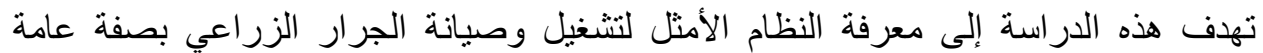

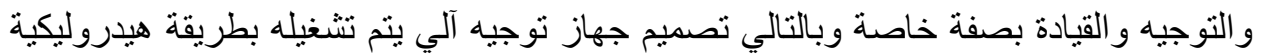

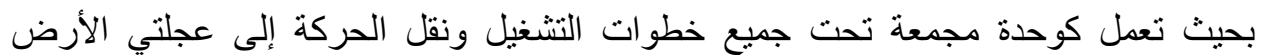

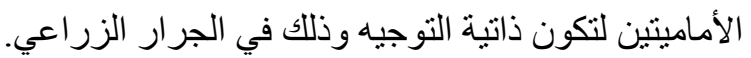

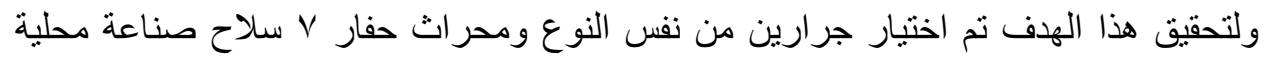

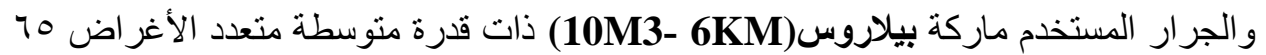

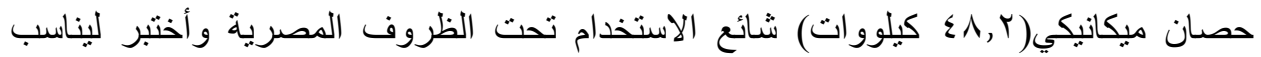

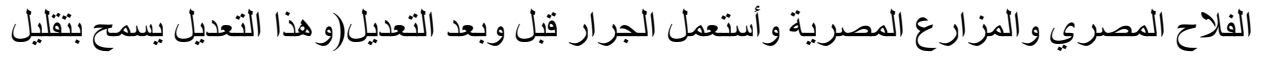

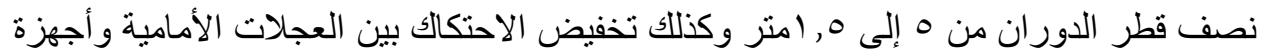

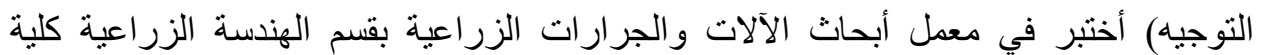
الزر اعة- جامعة الأز هر.

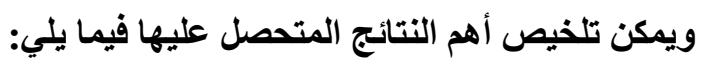

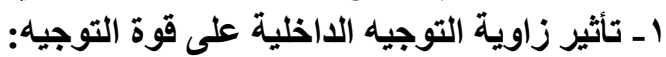

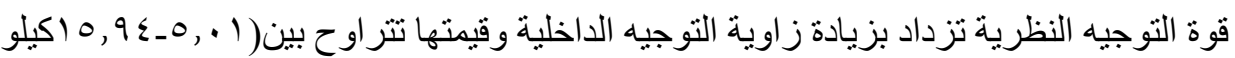

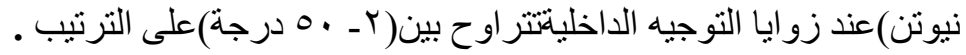

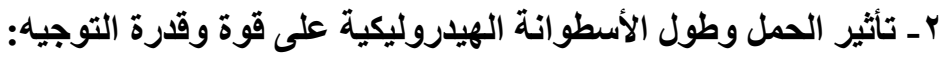

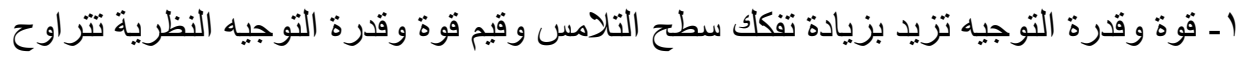

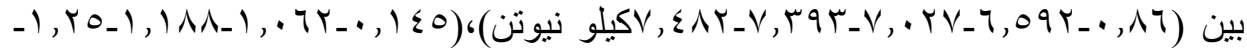

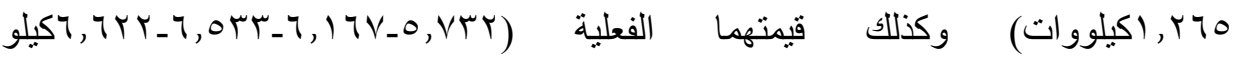

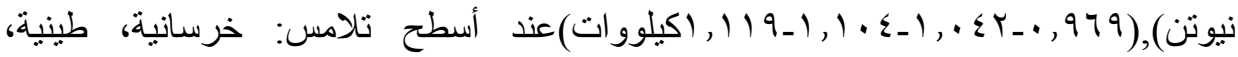

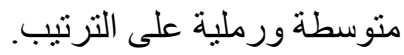

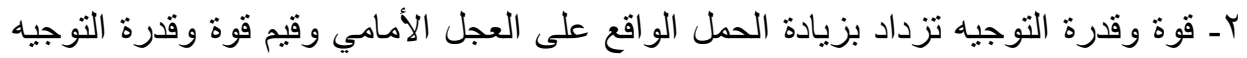

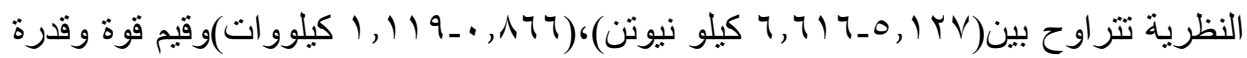

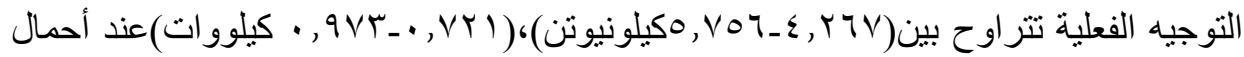

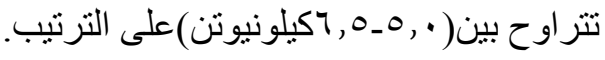

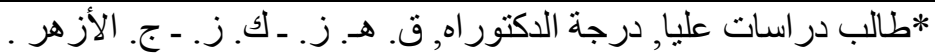

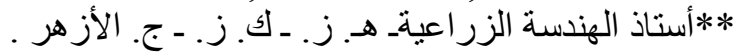

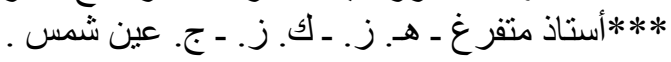


بـ تأثير السرعة وطول الأسطو انة الهيدروليكية على قوة وقدرة التوجيه:

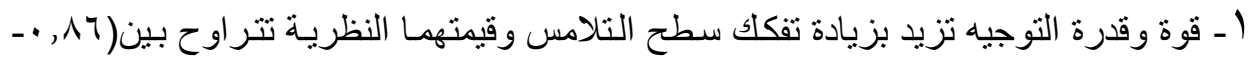

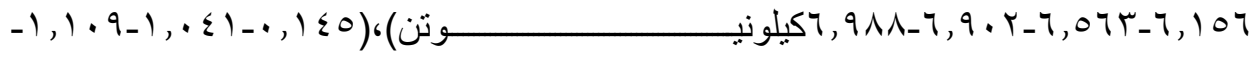

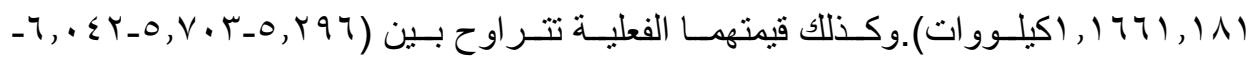

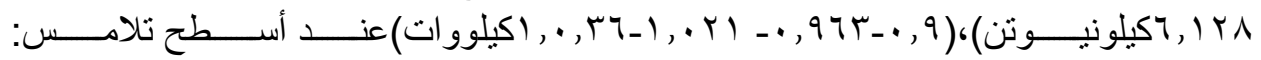
خرسانية،طينية، منوسطة ورملية على التئية

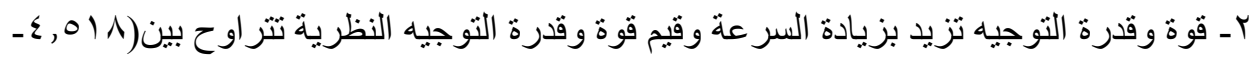

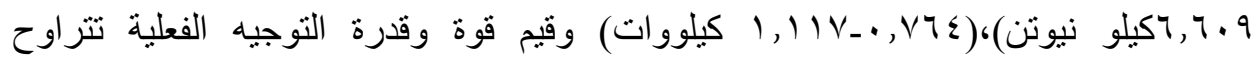

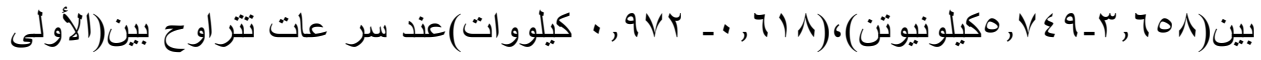

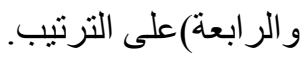

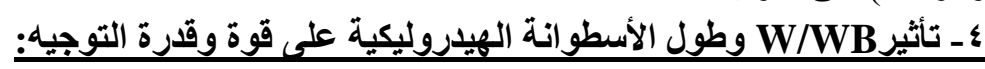

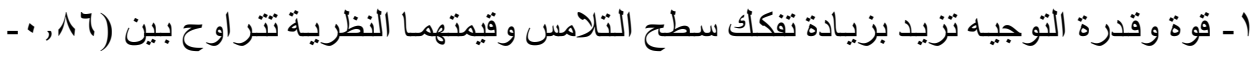

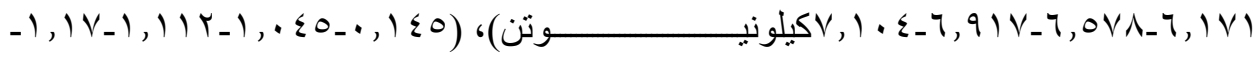

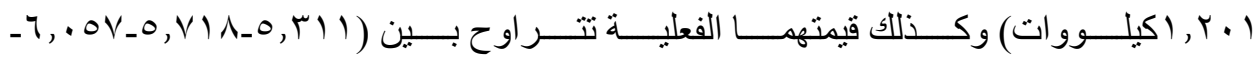

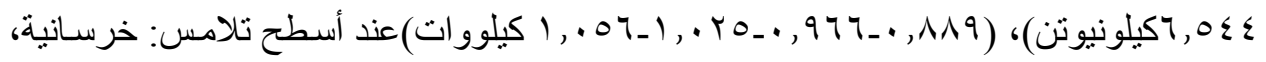
طينية، منوسطة ورملية على الترتيب.

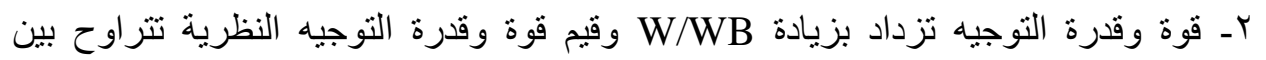

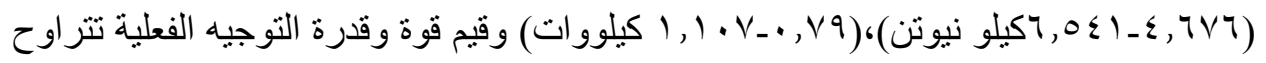

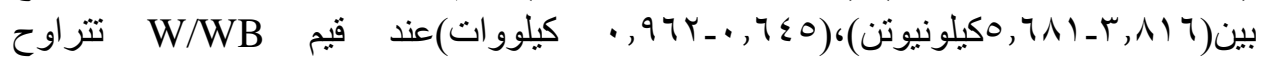

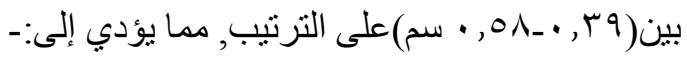

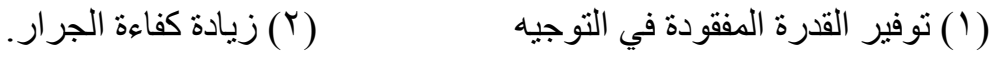

